Original Research Paper

\title{
Bulbophyllum acehense (Orchidaceae), A New Species of Section Beccariana From Aceh, Sumatra, Indonesia
}

\author{
Destario Metusala ${ }^{1^{*}}$ \\ ${ }^{1}$ Purwodadi Botanic Garden, Research Center for Plant Conservation and Botanic Gardens, Indonesian Institute of \\ Sciences (LIPI), Indonesia
}

\author{
Article history \\ Received : March $9^{\text {th }}, 2020$ \\ Revised : March 20"th 2020 \\ Accepted : March 23 ${ }^{\text {th }}, 2020$ \\ Published : March $26^{\text {th }}, 2020$ \\ *Corresponding Author: \\ Destario Metusala, \\ Research Center for Plant \\ Conservation and Botanic \\ Gardens, Indonesian Institute \\ of Sciences (LIPI), Indonesia \\ Email: \\ metusala.destario@gmail.com
}

\begin{abstract}
Sumatra island has been considered as one of the diversity centers for Bulbophyllum species in Indonesia. During botanical exploration held in the mid of 2019, specimens of the genus Bulbophyllum (Orchidaceae) section Beccariana have been collected from highland forests in Aceh Province, Sumatra, Indonesia. Their flower morphology and plant habitus are relatively close to Bulbophyllum cornutum (Blume) Rchb.f. (section Beccariana). Therefore, the aim of this research is to compare the Bulbophyllum sp. from Aceh with closely resemble species in section Beccariana, also to describe and illustrate the morphological characteristics of this Bulbophyllum species from Aceh. Morphological description was carried out by characterizing the flowers and plant habit of the living plants, spirit materials, dried herbarium specimens and photographs. Morphological comparisons with other closely resemble Bulbophyllum species were carried out based on data from protologue, living plants, herbarium specimens and several taxonomic references. The result based on morphological comparisons has showed there were several distinct differences on their flower characteristics, especially on the labellum. Therefore, this Bulbophyllum sp. from Aceh is here described and illustrated as new species, namely Bulbophyllum acehense.
\end{abstract}

Keywords: Bulbophyllum, Sumatra, Orchidaceae

\section{Introduction}

Indonesia is widely known as one of the richest countries in orchid species diversity. More than 4000 orchid species have been recorded from this country. In last 5 years, there are many of new orchid species have been discovered from Indonesian remote forests (Metusala, 2017a; Metusala \& Supriatna, 2017; Metusala \& O’Byrne, 2017; Metusala, 2019a, Metusala, 2019b). The trend of new orchid discoveries seems to be continuing, especially for large genera such as Dendrobium and Bulbophyllum.

The genus Bulbophyllum (Orchidaceae) has been recognized as the largest in orchid genera with about 2000 species from all over the world. This genus is naturally distributed from South America to Africa and Madagascar, throughout South Asia, China and Southeast Asia to New Guinea, Australia and Pacific Islands in the easternmost. However, the tropics forest of Asia has been considered as the major diversity center for this genus, where at least 1600 species occur in this area (Comber, 2001; Vermeulen et al., 2015).
As one of the major islands in Southeast Asia and also Indonesia, Sumatra with its tropical rain-forests is a habitat for more than 160 Bulbophyllum species. This number is actually relatively lower than Borneo Island with close to 300 Bulbophyllum species, and New Guinea Island with about 700 species, but a bit higher than Sulawesi Island (123 species) and Java Island with 90 species.

The botanical exploration of Sumatra is still far from complete. There are many biodiversity hot spots on this island remains underexplored, especially for mountainous primary forests in northern part of the island. Therefore, research-based collecting efforts should be done intensively in future to enhance our understanding about the actual orchid species richness in the island.

During botanical exploration held in the mid of 2019, the author has collected a species of wild-collected Bulbophyllum from Aceh Tengah District, Aceh Province, Sumatra. The flowered specimens of this Bulbophyllum have showed characters under the Beccariana section (Vermeulen \& O'Byrne, 2011; Vermeulen et al., 2015), such as having 1-flowered inflorescence, a basal node of 
the pedicel that only a little above the attachment of the floral bract, creeping rhizomes, and a median sepal with entire margins and 11-veined.

Detailed observation on these Bulbophyllum specimens (living, spirit and herbarium) has concluded that this taxon is undescribed species in which the flower morphology and plant habitus are relatively close to Bulbophyllum cornutum (Blume) Rchb.f. but with some distinct differences. Therefore, this taxon is here described as new Bulbophyllum from Aceh, Sumatra, Indonesia.

\section{Materials and Methods}

Materials and tools used in field exploration including Sony camera DSC-S730, GPS Garmin 78s, digital thermohygrometer, binocular, loupe, tweezers, hanging tags/labels for specimens, plastic bags, ethanol $96 \%$ for specimen preservation, field book, and stationary. Measurement and morphological description of the new species were based on examination of living plants, spirit material, and a dried herbarium specimen that were collected from natural habitat in Aceh Tengah, Aceh, Sumatra. Some of dried flowers were studied after softening in boiling water. The morphological measurement was conducted with the help of a loupe and a ruler with $0.5 \mathrm{~mm}$ accuracy. The comparison with other Bulbophyllum species in section Beccariana involved the study of their protologues, living plants, herbarium specimens, photographs, and also any related taxonomic references.

\section{Results and Discussion}

\section{A. Taxonomic Treatment and Morphological Description}

Bulbophyllum acehense Metusala, sp. nov. (Figs. 1-2) Type:-INDONESIA. Sumatra, Aceh Province, Aceh Tengah, RIO 9182 (holotype: BO!).

Diagnosis:-Bulbophyllum acehense is close to Bulbophyllum cornutum (Blume) Rchb.f. but differs in having broader elliptic-obovate petals, lower margin of column with a narrowly triangular acute tooth, oblong to oblong-obovate lip, apical lip that strongly curved backwards up to half of the lip length, and a distinct obtuse tooth below the stigma base (column foot).

Creeping epiphytic herb. Roots mainly below the pseudobulbs, greenish-brown to greenish-white, apical meristem part yellowish-orange. Rhizome 3-4.5 $\mathrm{mm}$ in diam., sometimes branched, section between pseudobulbs 2-3.5 cm long, rhizome scales fibres moderately persistent. Pseudobulbs distinct, ellipsoid to narrow ovoid, 2.5-3.7 cm high x 0.7-1.1 cm in diam., not angular, slightly flattened. Leaves 1-leaved per pseudobulb, petiole $0.8-2.3 \mathrm{~cm}$ long, blade narrowly elliptic, $11-17 \mathrm{~cm}$ long $x$ 2-2.7 cm wide, obtuse, leathery, mid vein prominent abaxially. Inflorescences from the base of pseudobulbs and from nodes on the rhizome, erect to patent, 3-8 cm long, 1-flowered, peduncle 1.2-2.3 cm long; scales 3-4, 0.5-1 cm long, glabrous; floral bracts obovate, $0.8-1 \mathrm{~cm}$ long $\mathrm{x} 0.6-0.75 \mathrm{~cm}$ wide, acute to acuminate, glabrous. Flower median sepal and petals not opening widely, $1.7-2 \mathrm{~cm}$ across, pedicel plus ovary $1.5-$ $4.8 \mathrm{~cm}$ long, basal node of pedicel just a little above the floral bract attachment at about $1 / 3$ times the diameter of the pedicel, median sepal and petals greenish yellow with longitudinal darker yellow and sometimes with reddish stripes, lateral sepals yellow with longitudinal red stripes, lip yellow to greenish yellow, column yellowish-white to greenish-yellow, anther white to yellowish. Median sepal free, recurved, elliptic to ovate, $1.4-1.6 \times 0.8-1 \mathrm{~cm}$, apex acute to acuminate, margins entire, glabrous. Lateral sepals free, obliquely ovate, falcate, $1-1.1 \mathrm{~cm}$ long $\times 0.8$ $1 \mathrm{~cm}$ wide, apex acute to acuminate, margins entire, glabrous, in natural shape are always strongly rolled backward. Petals free, spreading to slightly recurved, broad elliptic to slightly obovate, $1.4-1.5 \mathrm{~cm}$ long $\times 0.9$ $1.1 \mathrm{~cm}$ wide, obtuse to acute or sometimes acuminate, margins entire, glabrous. Lip strongly recurved near the base and the apex, oblong to oblong-obovate, $0.9-1.1 \mathrm{~cm}$ long x $0.5-0.6 \mathrm{~cm}$ wide, margin entire to minutely erose; adaxially slightly concave near base, with 3 ridges, lateral ridges start near the margins, close to the base, then converging slowly without meeting, running up to $2 / 3$ of the length of the lip and gradually disappearing near the apical part; in between these lateral ridges there is a median narrow cleft in the base, beyond this cleft is a median ridge about same height (or a bit lower) with the laterals, running up to $2 / 3$ of the length of the lip where it becomes slightly obscured; apical part of the lip is strongly curved downwards and backwards with a distinct median ridge that extends to the apex, this median ridge sometimes branched near the lip apex, lip apex obtuse or truncate or slightly retuse; adaxial surface glabrous except on the basal half of lateral ridges which are finely papillose; abaxially convex at basal median, with a low and narrow median furrow from the base to the apex, glabrous. Column including stelidia $0.5-0.6 \mathrm{~cm}$ long; stelidia very short, $0.8-1 \mathrm{~mm}$, sub-triangular, obtuse; lower margin with a large, patent, narrowly triangular, acute tooth, 2-3 mm long. Stigma semi-elliptic, below its base (at the column foot) with a distinct protruding obtuse tooth. Anther rather hemispherical with a protrusion in the front. Polinia 4, 0.8-1 mm. 


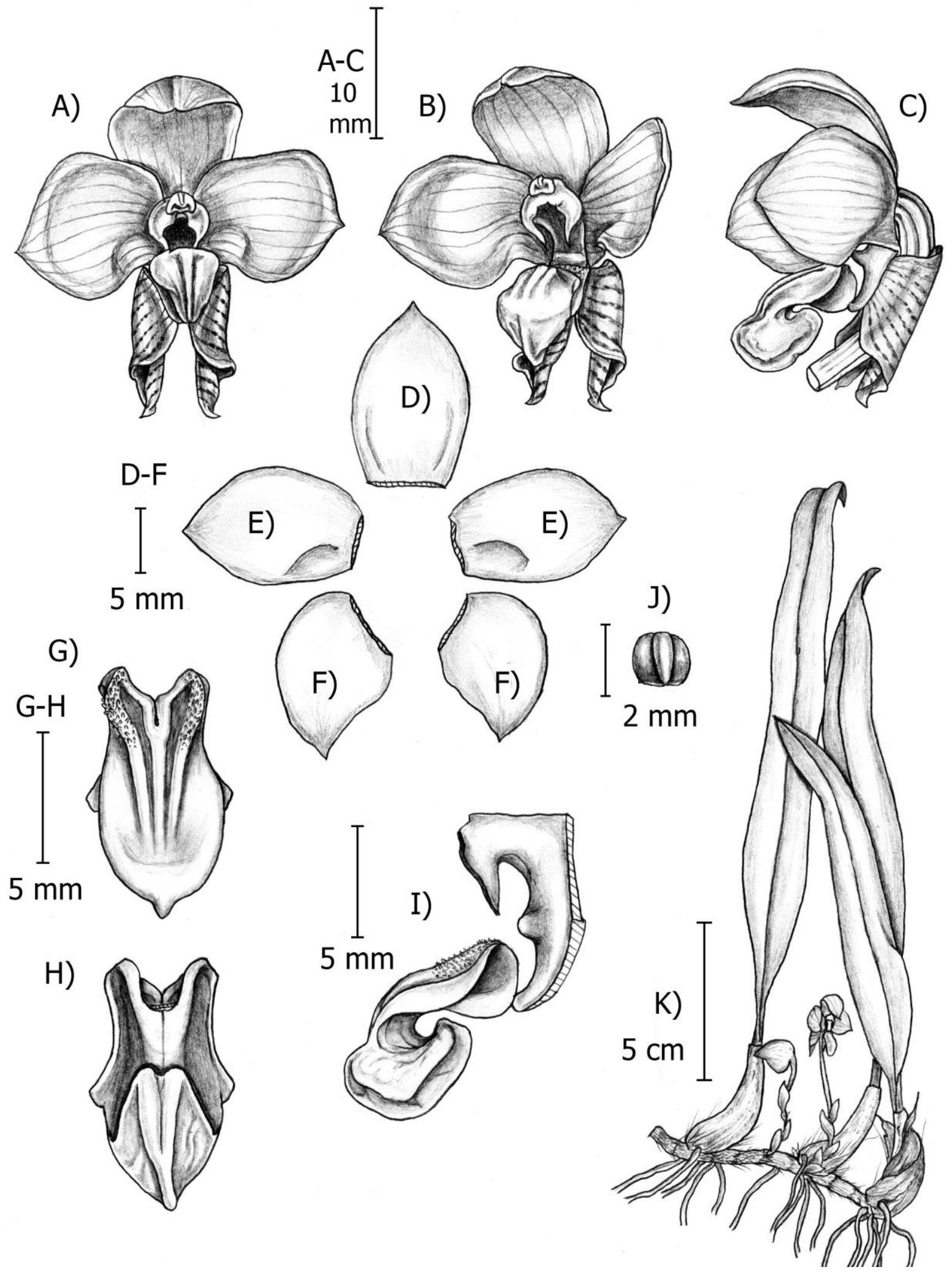

Figure 1. Bulbophyllum acehense. A-C, flower (A, front view; B, oblique view; C, side view); D, median sepal; E, petals; F, lateral sepals; G, lip (adaxial side); H, lip (abaxial side); I, column and lip (side view); J, anther (front view); K, plant. All drawn by Destario Metusala base on living and spirit specimens. 
B. Distribution, Phenology, Etymology and Cultivation

The natural distribution of this new species so far appears to be restricted to Aceh Province in the northern part of Sumatra Island, Indonesia. The forests of Aceh seem to show a high level of endemicity, especially for plant. Many of endemic plant species have been found restricted to the area of Aceh as well as northern part of Sumatra (Widjaja, 1997; Salmon \& Maulder, 1999; Comber, 2001; Akhriadi et al., 2004; Utami, 2006; Argent, 2006; Argent, 2015; Metusala, 2017a; Metusala $2017 \mathrm{~b}$ ). Therefore, this area should become a priority for the future botanical explorations (Metusala, 2017a).

Natural populations of $B$. acehense have been discovered in the semi-opened highland forest at 1300$1600 \mathrm{~m}$ with relatively high level of humidity. Flowering recorded in June-July and February-March. Etymology: This new species has been named after Aceh Province, the natural habitat where the type material originated. Cultivation: it can be grown by attaching the plant on a wood slab with some moss filling in the root area to maintain the humidity. Plant should be hung in a place with good air circulation, light intensity 50-75\%, and watered regularly, especially in the root area.

\section{Morphological Comparisons With Closely Resemble Species}

Bulbophyllum acehense is morphologically close to Bulbophyllum cornutum (Blume) Rchb.f., but differs in having broader elliptic-obovate petals $(0.9-1.1 \mathrm{~cm}$ wide), oblong to oblong-obovate lip, 3 longitudinal ridges on the adaxial surface of lip, apical lip that strongly curved backwards up to half of the lip length, lower margin of column with a narrowly triangular acute tooth, and a prominent obtuse tooth at the column foot. By contrast, $B$. cornutum has narrower elliptic-ovate petals $(0.35-0.55 \mathrm{~cm}$ wide), elliptic-ovate lip, 2 low longitudinal ridges on the adaxial surface of lip, apical lip somewhat recurved downwards, lower margin of column with a falcate or spathulate tooth, and below the stigma base (column foot) without any projection (Comber, 2001; Wood et al., 2011; Vermeulen et al., 2015).

Furthermore, B. acehense is also morphologically close to $B$. signatum J.J. Verm., but differs in having obtuse-acute petals, oblong to oblong-obovate lip, 3 longitudinal ridges on the adaxial surface of lip, apical lip that strongly curved backwards up to half of the lip length, adaxial lip that glabrous in the apical half, and a prominent obtuse tooth at the column foot. Meanwhile, B. signatum has caudate petals (cauda to $2 \mathrm{~mm}$ long), ovate lip, 2 or 4 longitudinal verrucose ridges on the adaxial surface of lip, apical lip slightly recurved, adaxial lip finely verrucose from base to apex, and below the stigma base (column foot) without any projection (Vermeulen et al., 2015).
An apical lip that strongly curved backwards up to half of the lip length is probably can be a unique character to distinguish Bulbophyllum acehense from the other Bulbophyllum species in section Beccariana. Another unique character of $B$. acehense is the strongly rolled backwards lateral sepals when in natural shape.

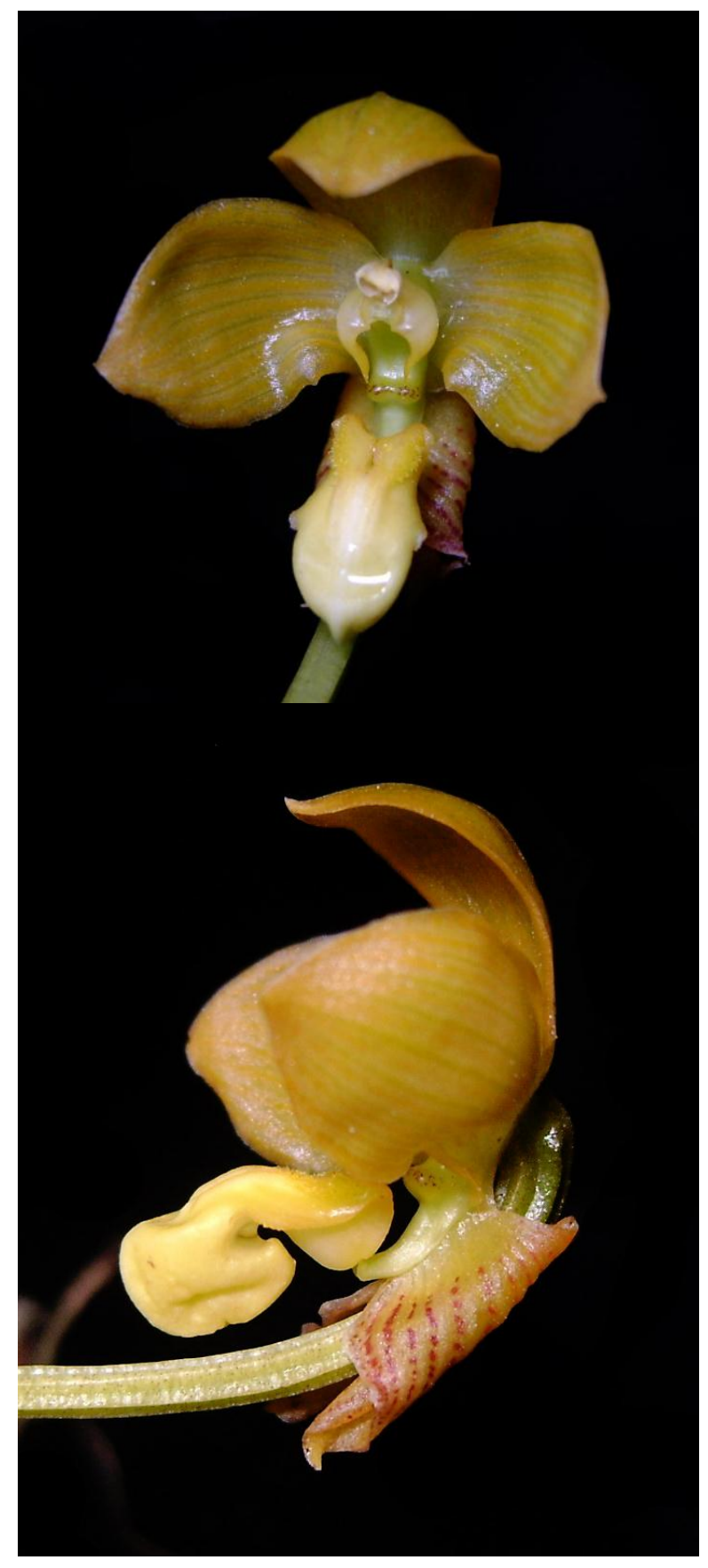

Figure 2. Bulbophyllum acehense. Flower: oblique view (above), side view (below). Photos by Destario Metusala. 


\section{Conclusion}

Bulbophyllum acehense has been described and illustrated as a new species from Aceh, Sumatra, Indonesia. This new taxa has showed distinct morphological differences to the closely resemble species, especially on its flower characters.

\section{Acknowledgements}

Author would like to express his gratitude to Tjiasmanto Conservation Fund for supporting the field exploration, Windra Suffan for his excellent assistance in preparing and carrying out the field work, Sultan F.R. for his kindness in preparing important chemical and facilitating the team in Banda Aceh, and local friends (Fajar, Afif, Thamrin, Rohman, and Januar) for their valuable help in facilitating the team during field exploration.

\section{References}

Akhriadi, P., Hernawati \& Tamin, R. (2004). A new species of Nepenthes (Nepenthaceae) from Sumatra. Reinwardtia 12(2): 141-144. https://doi.org/10.14203/reinwardtia.v12i2.56

Argent, G. (2006). Rhododendron of Subgenus Vireya Ed. 1. Royal Botanic Garden Edinburgh \& The Royal Horticultural Society, London. ISBN: 9781902896618, 388 pp.

Argent, G. (2015). Rhododendron of Subgenus Vireya Ed. 2. Royal Botanic Garden Edinburgh \& The Royal Horticultural Society, London. ISBN: 9781910877074, 454 pp.

Comber, J.B. (2001). Orchids of Sumatra. The Royal Botanic Kew, Richmond. ISBN: 1842460277 , 1026 pp.

Metusala, D. (2017a). Two new species of Paphiopedilum (Orchidaceae: Cypripedioideae) section Barbata from Sumatra, Indonesia. Edinburgh Journal of Botany 74(2): 169-178. DOI: https://doi.org/10.1017/S0960428617000063

Metusala, D. (2017b). A new variety of Paphiopedilum barbatum (Orchidaceae: Cypripedioideae) from Sumatra, Indonesia. Pro-Life 5(1): 467-475. http://ejournal.uki.ac.id/index.php/prolife/article/v iew/483
Metusala, D \& Supriatna, J. (2017). Gastrodia bambu (Orchidaceae: Epidendroideae), a new species drom Java, Indonesia. Phytotaxa 317(3): 211-218. DOI: http://dx.doi.org/10.11646/phytotaxa.317.3.5

Metusala, D \& O'Byrne, P. (2017). Phalaenopsis kapuasensis (Orchidaceae), a new species from Kalimantan, Indonesian Borneo. Pro-Life 4(3): 386-391. http://ejournal.uki.ac.id/index.php/prolife/article/v iew/434

Metusala, D. (2019a). Dendrobium nagataksaka (Orchidaceae: Epidendroideae), a new species of section Spatulata from Papua, Indonesia. Phytotaxa 415(5): 271-278. DOI: http://dx.doi.org/10.11646/phytotaxa.415.5.3

Metusala, D. (2019b). A new name for an overlooked species of Eulophia (Orchidaceae) from Wallaceae. Phytotaxa 415(4): 217-224. DOI: http://dx.doi.org/10.11646/phytotaxa.415.4.6

Salmon, B.R. \& Maulder, R.G. (1999). Notes on Nepenthes from northern Sumatra. Carnivorous Plant Newsletter 28(1): 14-18. https://legacy.carnivorousplants.org/cpn/Species/ v28n1p14_18.html

Utami, N. (2006). Impatiens spp. (Balsaminaceae) endemik di Sumatera dan potensinya sebagai tanaman hias. Biodiversitas 7(2): 135-138. https://doi.org/10.13057/biodiv/d070209

Vermeulen, J. \& O’Byrne, P. (2011). Bulbophyllum of Sulawesi. Natural History Publications (Borneo), Kota Kinabalu. ISBN: 9789838121378, 247 pp.

Vermeulen, J., O’Byrne, P. \& Lamb, A. (2015). Bulbophyllum of Borneo. Natural History Publications (Borneo), Kota Kinabalu. ISBN: 9789838121569, 728 pp.

Widjaja, E.A. (1997). New taxa in Indonesian bamboos. Reinwardtia 11(2): 57-152. http://ejournal.biologi.lipi.go.id/index.php/reinwardtia/ar ticle/view/588/387

Wood, J.J., Beaman, T.E., Lamb, A., Lun, C.C. \& Beaman, J.H. (2011). The Orchids of Mount Kinabalu. Royal Botanic Garden, Kew and Natural History Publications (Borneo), Kota Kinabalu. ISBN: 9789838121330, 726 pp. 